\title{
Legal Regulations for Advertising Vocational Education and Training Services: Case Study of Lithuania
}

\author{
Vidmantas Tutlys, (Assistant professor, PhD) \\ Genute Gedviliene, (Professor, PhD) \\ Vytautas Magnus University, Lithuania \\ Skaiste Vaiciukyniene, (MA)
}

Kaunas University of Applied Engineering Sciences, Lithuania

Doi:10.19044/esj.2018.v14n22p202 URL:http://dx.doi.org/10.19044/esj.2018.v14n22p202

\begin{abstract}
The European Commission's Europe 2020 strategy calls for the enhancement the attractiveness of vocational education and training. This article aims to disclose and critically discuss the requirements defined in legislation of Lithuania for advertising VET services with reference to the context of the improvement of the VET image in society. It seeks to determine the requirements stipulated in legislation of Lithuania for advertising VET services and to evaluate the information on admissions to institutions of vocational education and training on their web pages according to the criterion of truthfulness of advertising. The article may be useful for professionals who work or will work with marketing communication in the future. It can be used as a manual of how to inform customers about VET services properly. The methods applied in this research are content analysis of scientific literature and legal documents, linguistic, comparative, systematic and logical interpretation methods of law, and a qualitative content analysis used for the case study. The content of the training service and not the subjective image is the actual marketing object, because the content provides an advantage that ensures good market positions in increasingly competitive market of VET provision. The image of initial vocational education is determined not so much by the actions of society, but by the vocational training systems themselves, or more specifically by the targeted efforts of its participants to improve the quality of initial vocational education, responding to the public challenges and communicating this message to the interested audiences in the communication process.
\end{abstract}

Keywords: Vocational education and training services, image of vocational education and training services, advertising, marketing, legal regulation. 


\section{Introduction:}

According to The Bruges Communiqué on enhanced European Cooperation in Vocational Education and Training (Communique of the European Ministers for Vocational Education and Training, the European Social Partners and the European Commission, 2010) "Europe is trying to recover from a severe economic and financial crisis. Unemployment rates are high in particular amongst young people. The crisis has emphasised the need to reform our economies and societies. Europe wants to become smarter, more sustainable and more inclusive. To achieve this we need flexible, high quality education and training systems which respond to the needs of today and tomorrow." Vocational education programmes are "designed for learners to acquire the knowledge, skills and competencies specific to a particular occupation, trade, or class of occupations or trades" (UOE, 2018). The purpose of such type of education is to help a person to acquire, change or improve his/her qualifications and be prepared for participation in a changing labour market.

\section{Problem of Research}

Vocational education and training could be an engine of innovation and growth in every country, but, for example, based on the 2014-2016 action plan for the VET development (Order of the Minister of Education and Science of Lithuania, No. V-851, 2014), in Lithuania only about $33 \%$ of young people (the European Union average $-50 \%$ ) are choosing vocational training, others choose their studies at higher education institutions immediately after the general education school or enter the labour market without professional preparation. More than one fifth of the employed (22.9\%) work without qualifications (completed only primary, basic or secondary education programs). The European Commission's Europe 2020 strategy (2010) calls for the enhancement of the attractiveness of vocational training, for promoting education and business partnerships, and for ensuring that people's professional career takes as long as possible: to enable them to acquire new skills at any stage of their life by enhancing the attractiveness of continuing education and by creating a flexible modular vocational training program compatible with the needs of the labor market.

One of the approaches which can be used to achieve the goal of enhancing the attractiveness of vocational training set in the Europe 2020 strategy is a good image of the VET sector. It will, however, be difficult to implement, because in some countries "vocational education suffered from social stigma in light of it's less prestigious image" (Chong, 2014). For example, poor image of the initial vocational education and training in Lithuania is to a large extent a legacy of the Soviet period, when the VET system was used for segregation of less performant students and there was a 
rather widespread belief that learning in the VET schools was of low value and outdated (Lauzackas et al., 2004). So, a good image of VET services would lead to more gifted young people choosing vocational training, such young people would graduate with better results and could be more easily employed by companies (Clement, 2014). Therefore, one of the key tasks of a VET provider is to become an attractive and flexible educational institution which would provide optimal possibilities for acquisition of qualification in a highly competitive environment of vocational and higher education providers. There has been a significant increase in business-like characteristics and processes in the activities of VET providers, especially in the area of management, marketing of training services and their quality improvement (Liesionis and Cepaite, 2012). According these authors "the survival and success in the competitive market of educational services highly depends on its positive and solid image", which helps learners to make a choice in favour of VET. The positive image of an organisation is not the result of a random action - significant efforts are required by an educational institution to create and maintain a positive image especially during the phases of the development and management of the image (Druteikiene, 2002), and nowadays building of a successful image becomes one of the strategic objectives of an educational institution (Urneziene and Tolstych, 2015).

Liesionis and Cepaite (2012) claim, that the image of the initial VET provider is usually shaped by 1) information obtained via direct communication or communication in the media, 2) experience and 3) communication as a result of the marketing and communication efforts of the VET provider. Vuori (2015) states that "the role of marketing communication is to provide information which helps the informed customer to make the right decision" and that "the communication should be so convincing that it leads to action", because "the goal of market differentiation is to communicate to the target audience how the offered product or services suit customer requirements better that any other available option." Vocational education and training is a type of services to which we can apply service marketing theories, describing students as customers and communicate to them that our services suit their requirements better than other offers. According to Mortimer (2000), "informative advertisement provides information which is of use in making comparisons between alternatives and increases the consumer's knowledge of the brand being promoted", but nowadays advertising became "communications that have the goal of persuading consumers about products, services and brands" (Johar, 2016). In this case ability to choose information properly and to make the right decision are very important in the selection process of any kind of education, especially of vocational education and training, where the information reaches the customers before their full age. Sometimes we can use marketing communication in such a way that the person 
to whom the information is intended will not be able to choose information properly, because the information could be misleading or we could use hidden advertising with the purpose to attract customer attention.

Advertising of VET is highly relevant in Lithuania, because the audit of practical training centres in vocational schools (2016) in Lithuania by the National Audit Office (No. VA-P-50-1, 2016) found that not all centres were properly planning how to attract new customers and to sell their services, some of them even did not have the ability to implement these plans. Furthermore, the research conducted by Urneziene and Tolstych (2015) revealed that the initial VET providers often lack clear strategies on how to use the measures of dissemination related to public relations and management of an educational institution. At the national policy level, one of the objectives in the strategic plan for the development of vocational education and training in the period of 2014-2016 approved by the Ministry of Education and Science (Order No. V$851,2014)$ was to increase the attractiveness of vocational education and training. The plan also foresaw the measures for attainment of this objective, such as improvement of the image of vocational education and training in society, presentation of the services by VET providers to the wider society and general education establishments, organization of the skills competitions of VET students, facilitating increase of the involvement of associated business structures and bodies in the management of VET schools, and improvement of the conditions for students from social risk groups to seek and to attain vocational qualifications.

\section{Research Focus}

This article aims to disclose and critically discuss the requirements defined in legislation of Lithuania for advertising vocational education and training services with reference to the context of the improvement of the VET image in society. It is very important to identify these legal requirements, because marketing communications, which are in nature promotional messages delivered through various types of channels, can materially distort the economic behaviour of the consumer with regard to the product or service and he/she may take an incorrect decision concerning the product or service. The article may also be useful for professionals who work or will work with marketing communication in the future. It can be used as a manual of how to inform customers about vocational education and training services properly.

\section{Methodology of Research}

\section{General Background of Research}

\section{The duty to provide information about education}

The main legal documents, which regulate vocational education and training services in Lithuania, are the Law on Education of the Republic of 
Lithuania (2011) and the Law on Vocational Education and Training of the Republic of Lithuania (2017).

Education is treated as a fundamental human right by the Law on Education. Article 26 entrenches the obligation to provide information about educational possibilities. Information about programs of formal and nonformal education, enrolment terms, teachers' qualification, results of the assessment of educational establishments, traditions and attainments of the school community must be accessible for public. Information on education is oriented to the needs of a person and should help him/her to make choices about education, future occupation, qualification and career according to his/her interests and capabilities. Such information should provide guidance in choosing the level and field of education as well as the provider. This requirement if fulfilled through the services of vocational information and guidance which includes the information about the access to initial vocational training and higher education in the country and abroad, as well as information about employment prospects in Lithuania. Such guidance and information are provided in the schools, vocational guidance centres and national employment offices.

The vocational education and training system in Lithuania consists of initial vocational education and training, available for persons from 14 years of age and continuing vocational education and training (both formal and informal). Another important field of the VET system is vocational guidance. According to the Law on Vocational Education and Training (Article 5) vocational guidance comprises provision of information on vocations, occupations and training possibilities, as well as vocational counselling. It may focus on the provision of guidance and recommendations for occupational choices or may be a measure which enhances to choose the pathways of vocational education or higher education. The laws in Lithuania promote a modern concept of vocational guidance as services helping to make rational decisions on the career choice and to offer relevant educational possibilities, as well as to acquire competences that help to design and develop own career (Description of the Procedure for Carrying out Vocational Guidance, Article 2, 2012).

Vocational guidance is executed by providing the services of career education, vocational information (including enactment) and vocational counselling (Ministry of Education and Science of the Republic of Lithuania, 2014). Vocational guidance is defined as systemic provision of information on the issues of vocational education and training, demand of qualifications in the labour market and occupational choice. Vocational guidance of students enables them to access and discuss information about vocational learning and work opportunities in the schools. In addition, vocational guidance also involves enactment, creating a direct contact with real work activities by 
observing such work activities, executing activities practically and training in enterprises. In the process of enactment students actively familiarize with various employment areas, occupational characteristics and career opportunities, and they start acquiring work experience, develop professional motivation and plan future employment. Meanwhile, during vocational counselling, students are provided an opportunity to understand, evaluate and discuss individual qualities that can influence career development, further learning, and career choices. Vocational guidance must be guided by the following principles: 1) accessibility, i.e. the service is provided to all persons, 2) impartiality, free choice and personal responsibility for career decisions, 3) individualism and quality of service - vocational guidance providers are responsible for high quality of their services and compliance with ethics and professional conduct (Description of the Procedure for Carrying out Vocational Guidance, Article 4, 2012).

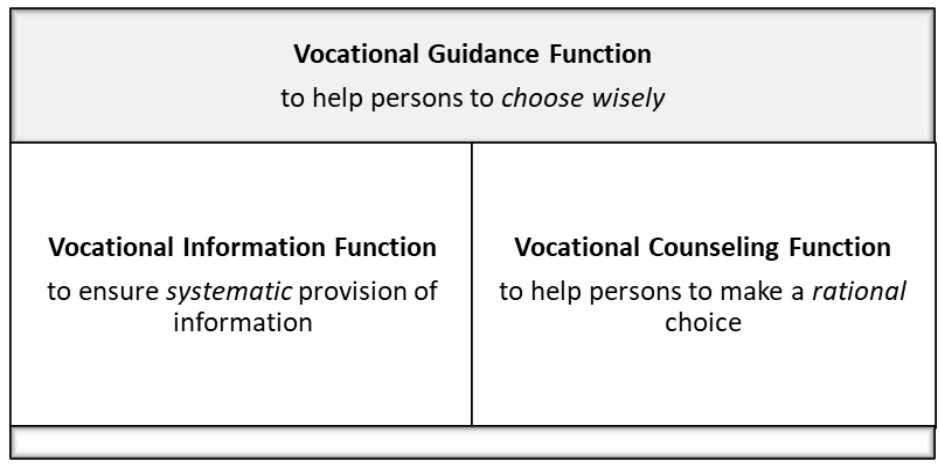

Figure 1. Concept of vocational guidance

Taking into account that the provision of information on education is a mandatory obligation for schools and this information must be made public, based on the concept of vocational guidance (Table 1) we can identify the main rules for information activities of vocational education and training services:

- systematic provision of information (ongoing process),

- the information must help the person to choose wisely and make a rational choice of the profession by taking into account his individual qualities, the needs of the labour market and opportunities for vocational training (purpose of the information);

- vocational guidance must be carried out in accordance with the principles of impartiality, free choice and personal responsibility for career decisions (behavioural model for vocational guidance providers). 


\section{Legal documents, which regulate the Advertising of Vocational Education and Training Services in Lithuania}

The main legal documents which regulate advertising activities in Lithuania are the Law on Advertising of the Republic of Lithuania (2000) and the Law on the Prohibition of Unfair Business-to-Consumer Commercial Practices of the Republic of Lithuania (2008)

Advertising is defined as information dissemination in any form and by any means relating to the economic, commercial, financial or professional activities of a person where it promotes the purchase of goods or services (Law on Advertising, Article 2[8]). The main requirements for advertising activities are set out in the documents. There are three main areas of requirements for advertising activities:

- requirements for the content of advertisement,

- requirements for the form of advertising,

- requirements for the commercial practice of advertising activity.
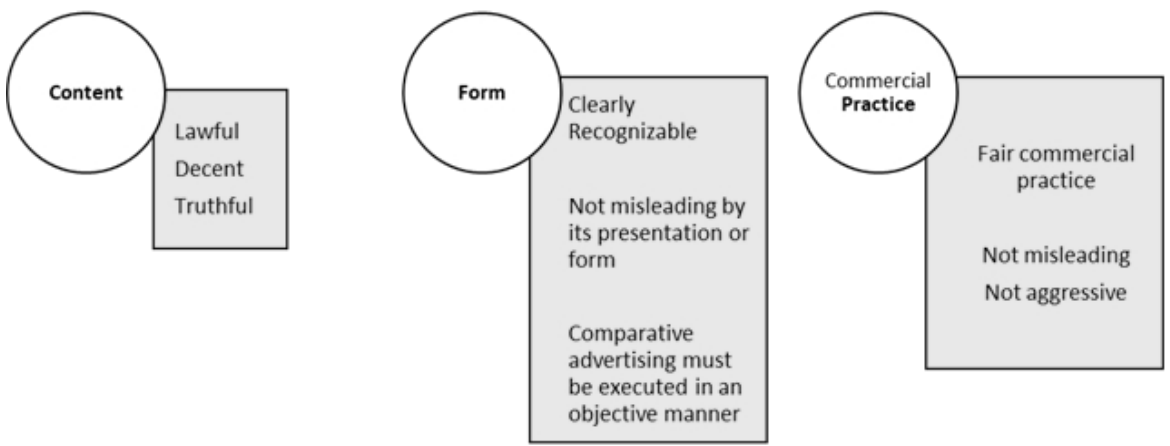

Figure 2. Requirements for advertising activities

The content of advertising must be lawful, decent and truthful. Some general requirements for advertising are in place: the requirements of the Law of the Republic of Lithuania on the State Language apply to a written and audio text of advertising and advertising is prohibited where it violates principles of public morality, degrades human honour and dignity, incites national, racial, religious, gender-related or social hatred and discrimination as well as defames or misinforms, promotes coercion and aggression and gives rise to panic, promotes behaviour which poses a threat to health, security and the environment, abuses superstitions, people's trust and their lack of experience or knowledge, makes a reference to the name and surname of a natural person without his consent, presents his opinion, information about his private or public life and property and makes use of the natural person's image, uses special subliminal means and technologies in advertising dissemination, uses advertising material which has been prepared in violation of copyright to 
works of literature, art and science and/or related rights and scorns religious symbols of the religious communities registered in Lithuania (Law on Advertising, Article 4).

Decent advertising means that it shall not violate the prevailing standards of decency in society, for example, good taste, decency or respect for human dignity. Truthful advertising means that you shall not misinform or intentionally mislead consumers (Constitutional Court of the Republic of Lithuania, 2005). The use of misleading advertising is prohibited. When judging whether or not advertising is misleading the following three criteria must be taken into account: accuracy, comprehensiveness and presentation (Law on Advertising, Article 5[1]). Claims presented in advertising are considered false, if the provider of advertising cannot substantiate accuracy of the assertion during the time the advertising is used (Law on Advertising, Article 5[2.2]) The information presented in advertising is incomplete if a certain part of the information has been omitted, where the presentation thereof is, taking account of another information presented in such advertising, necessary in order to avoid misleading of consumers of advertising. The information presented in advertising shall also be considered as incomplete if material information is undisclosed, concealed or is provided in an obscure, incomprehensible, ambiguous or untimely manner, where the average consumer needs this information to be able to make an informed transactional decision and thus causes or is likely to cause the average consumer to take a transactional decision that he would not have taken otherwise (Law on Advertising, Article 5[2.2]).

The form of advertising must be clearly recognizable, not mislead by its presentation or form and comparative advertising must be executed in an objective manner. Hidden advertising is prohibited. Advertising must be clearly identifiable according to its form of presentation. Where there exists the likelihood that due to the form of presentation, consumers of advertising may not identify the advertising disseminated in the media, such advertising must be marked with the word "advertisement" (Law on Advertising, Article 8). If the manner or form of presentation of advertising is such that the consumer of advertising may perceive an implied inaccurate/misleading claim of advertising, it will be considered to be misleading advertising (Law on Advertising, Article 5[2.3]). Comparative advertising must be not misleading, compare goods or services meeting the same needs or intended for the same purpose. Advertising objectively compares one or more material, relevant, verifiable and representative features of the goods or services, which may include price, but it does not create confusion among operators of commercial activity, between the supplier of advertising and a competitor or between the supplier of advertising's trade marks, trade names, other distinguishing marks, goods or services and those of a competitor. Advertising does not discredit or 
denigrate the trade marks, trade names, other distinguishing marks, goods, services, activities, financial or other circumstances of a competitor. For products or services with designation of origin, advertising relates in each case to products or services with the same designation. It does not take unfair advantage of the reputation of a trade mark, trade name or other distinguishing marks of a competitor or of the designation of origin of competing products or services, advertising does not present goods or services as imitations or replicas of goods or services bearing a protected trade mark or trade name (Law on Advertising, Article 5[2.3]).

The Law on the Prohibition of Unfair Business-to-Consumer Commercial Practices of the Republic of Lithuania regulates commercial practice. According to this law, commercial practice means "any act, omission, course of conduct or representation, including advertising and marketing, by a trader, directly connected with the promotion, sale or supply of a product to consumers" (Unfair Business-to-Consumer Commercial Practices, Article 2[4]). Unfair commercial practice is prohibited (Unfair Business-to-Consumer Commercial Practices, Article 3[1]). Misleading commercial practices and aggressive commercial practices are the most common unfair commercial practices. Misleading actions or misleading omissions shall be regarded as misleading commercial practices (Unfair Business-to-Consumer Commercial Practices, Article 4). A commercial practice shall be regarded as aggressive if by harassment, coercion, including the use of physical force, or undue influence, it significantly impairs or is likely to significantly impair the average consumer's freedom of choice or conduct with regard to a product and thereby causes him or is likely to cause him to take a transactional decision that he would not have taken otherwise (Unfair Business-to-Consumer Commercial Practices, Article 8). Also, there is a "black list" of misleading commercial practice that need not to be proved (Unfair Business-to-Consumer Commercial Practices, Article 8), for example, false claiming that a trader is bound by a code of conduct; displaying a trust mark, quality mark or an equivalent mark without having been granted such a right; false claiming that the trader (including his commercial practices) has been granted a licence/authorisation, or a false statement that a product has been approved (a procedure for verifying the conformity of the product with the set requirements (legal acts, standards, etc.) has been performed; making a commercial offer indicating the price without disclosing the existence of any reasonable grounds the trader may have for believing that he will not be able to offer for supply, or to designate another trader to supply, those products, or equivalent products, at that price for a period that is, and in quantities that are, reasonable having regard to the product, the scale of advertising of the product and the price offered; making a commercial offer at a specified price and then refusing to show the advertised product to consumers or refusing to take orders 
for the product or to deliver it within a reasonable time or demonstrating a defective sample of it, with the intention of promoting a different product; false claiming that a product will only be available for a very limited time, or that it will only be available on particular terms for that period of time, in order to elicit an immediate decision and deprive consumers of sufficient opportunity or time to make an informed choice; making a materially inaccurate claim concerning the nature and extent of the risk to the personal security of a consumer or his family if the consumer does not purchase the product; promoting a product similar to a product made by another manufacturer in such a manner as deliberately to mislead a consumer that the product is made by that other manufacturer; false claiming that the trader is about to cease trading or change a point of sale; claiming that products are able to facilitate winning in games of chance; passing on materially inaccurate information on market conditions or information where to find a product with the intention of inducing the consumer to acquire the product at conditions less favorable than normal market conditions; claiming in a commercial practice to offer a competition or prize promotion without awarding the prizes described or a reasonable equivalent; describing a product as "without charge" or similar if the consumer has to pay anything other than the unavoidable cost of responding to the commercial practice (e.g., the customer's postal or telephone expenses in accordance with the usual rates, etc.) and expenses relating to collecting or paying for delivery of the item; including in marketing material an invoice or similar payment document which gives the consumer a false impression that he has already ordered the marketed product; false claiming or creating an impression that the trader is not acting for the purposes relating to his trade, business, craft or profession, or falsely representing oneself as a consumer; or advertising a product through the mass media for payment or any other consideration from the trader where such advertising is not properly marked or separated from the editorial content by images or sounds clearly identifiable by the consumer as advertising.

Since the Law on Education of the Republic of Lithuania (Article 26) obliges schools to publish information about the programs of formal and nonformal education, their choices, access conditions, paid education services, teacher qualifications, the main results of the school's external evaluation, school community traditions and achievements in public, the provision of information is regulated by the Law of the Republic of Lithuania on Provision of Information to the Public (2006). This law defines public information as information intended for public dissemination (Article 2[78]) and its content requirements, i.e. public information in the media must be fair, accurate and impartial (Article 3[3]). The media for dissemination of information means a newspaper, magazine, newsletter or other publication, book, television program, radio program, cinema or other audiovisual production, information 
society media and other means of disseminating information (Article 2[86] 2[86]). Public information disseminator is an owner or holder of an information society media or another person who distributes public information to the public and is responsible for the lawfulness of this information (Article 2[80]). This law defines advertising as any form of advertising or self-advertising for any purpose, disseminating information on economic, commercial, financial or professional activities and promoting the purchase of goods or services (Article 2[57]).

According to the case law of the Constitutional Court, advertising is also classified as information, as it gives the recipient some knowledge of the goods, services or other advertised objects/entities. Advertising is information, but all information is advertising. Advertising is a specific piece of information, which is called commercial information and which is inseparable from the business sphere and marketing, since it actually serves them and is an important tool of competition. The main purpose of advertising is to promote relevant products, to shape their favourable image and to encourage their use, either directly or indirectly (Constitutional Court, 1997).

The freedom of information is enshrined in the Constitution of the Republic of Lithuania (Article 25) and it includes the freedom of advertising. Freedom of information is generally treated in a broad sense and includes freedom of speech, freedom to express opinions and attitudes, the right to receive and disseminate information and ideas, freedom of the press and other information media. Freedom of information means not only the right to inform (disseminate information) but also the right to receive information. Incorrect information, i.e. disinformation is prohibited by law. Thus, the information, including advertising, is subject to the requirement of truth (Constitutional Court, 1997). Besides, advertising for goods or services - whether or not these activities are commercial (for profit) or not - are always aimed, directly or indirectly, at encouraging the use of certain goods or the use of certain services. Such use may also be encouraged by information that is not initially intended to encourage it to be promoted (for example, statistics, technical and other knowledge, in which something is being made known, attention paid to something, etc.). Disseminating such information in certain circumstances may have the same effect on the recipients of the information as advertising, and therefore, is regarded to be equal to advertising. Also, the information disseminated is not necessarily purely advertising or only non-promotional: information, dissemination of which is not advertising, may include elements of promotional content (Constitutional Court, 2005). In practice, advertising in the case law is often interpreted in the widest possible ways, and when there is at least the slightest doubt as to whether dissemination of information is considered as advertising, it is generally inclined to recognize this information as advertising (Markauskas, 2010). 
In concluding it can be stated, that schools have a right and even obligation to publish information on education possibilities, to offer vocational guidance services in order to help people to consciously choose suitable education and employment opportunities and to implement the fundamental human right - freedom of information. However, it should be considered that freedom of information, including freedom of advertising, is often a precondition for the exercise of the rights and freedoms of others. Therefore this freedom is not absolute and may be restricted in order to protect other constitutional values necessary for a democratic society (Markauskas, 2008). The freedom of information is subject to the requirement of truth, because "when receiving information provided as advertising, individuals exercise their right to know, i.e. the right to information" (Markauskas, 2009). Anyone who disseminates information must observe the restrictions provided by law and not abuse the freedom of information (Constitutional Court, 1995). The legal requirements help to protect consumers' needs, but it is up to professionals to ensure that they would use the information for advertising honestly and avoid misleading information, unsuitable comparative advertising or unfair trade practices.

\section{Methods of Research and Data Analysis}

The methods applied in this research are content analysis of scientific literature and legal documents, linguistic, comparative, systematic and logical interpretation methods of law, and a qualitative content analysis used for the case study.

Research questions of this study are:

1. To determine the requirements stipulated in legislation of Lithuania for advertising vocational education and training services;

2. To evaluate the information on admissions to institutions of vocational education and training on their web pages according to the criterion of truthfulness of advertising.

\section{Results of Research}

\section{Case study - evaluation of information on admissions according to the criterion of truthfulness}

Vocational training in Lithuania can be provided by any school, institution or enterprise licensed to provide vocational training services. There are 74 vocational education and training institutions in Lithuania. For the present case study websites of these institutions were analysed and information, used to convince potential students was critically evaluated according the criterion of truthfulness of advertising. The focus of this analysis was information on admissions, as the positive image of a VET institution starts with its vocational training programs that are adapted to the needs of 
students and the public (Catri, 1998). According to Lesionis and Cepaite (2012), the image of a VET institution is important for the purpose of attracting as many learners as possible and it is usually formed from messages generated as a result of direct communication efforts. According to these authors, each VET institution should pay attention to the fact that the provision of public information (for example, to the institution's website or social networks) does not cost anything, therefore, it is necessary to invest in creating positive impressions and to keep in mind that advertising means purposefully presenting positive information about the organisation. The major share of information provided on the pages of the websites of VET schools and dedicated to admissions consists of the information about training programs, whereas the information about the benefits of a particular institution is very fragmented. In order to evaluate the information according to the criterion of truthfulness of advertising, we used the document of the Competition Council of the Republic of Lithuania "Misleading and inadmissible comparative advertising guidelines” (2016).

After reviewing marketing messages used for recruiting students we have identified 13 institutions with the information on their websites which could be considered as misleading and not meeting the requirement of truthful advertising or public information. Statements provided in advertising are regarded as misleading when the purchaser/provider cannot support the truthfulness of the claims in the course of the use of advertising (Law on Advertising, Article 5).

The most likely violations were identified in the presentation of the prospects of the profession, for example, "the work of the decorator (builder) is important, the demand is constantly growing, as each newly built or repaired structure awaits the hands of the specialists of this profession", "demand and employment for a kitchen assistant are always readily available because catering is a popular business and there is a strong demand for professionals in this field", "demand for electric and gas welders is high, work prospects are good, very good salaries", "the profession of the cashier and accountant is quite in demand", or "in three years of studies you will not only graduate from high school, but will also obtain an interesting specialty which is in demand". The examples show that to make study programs more attractive, the phrase "profession in demand" is mostly use without any evidence of this. According to "Misleading and inadmissible comparative advertising guidelines", the criterion of truthful advertising obliges the subject of advertising activities to have sufficient data to substantiate advertising claims. In the said cases there is no evidence for advertising claims. It can be a big problem when people rely on expectations of their future profession and the demand for such profession on the labour market that are not objective. 
It is evident that the image of a VET institution and the attractiveness of a VET curriculum depend on the extent that they lead to the acquisition of competences and qualifications demanded in the labour market. When it is declared that a certain training program or curriculum is the most attractive, most desirable and most popular among employers, such statements must be supported by objective evidence, i.e. statistical data must be provided. Referring to Terebeiza (2011), the truth, which depends on subjective conditions, is not the truth but the illusion of truth. Such truth is subjective and cannot be separated from the false statement, because what is truth for one person cannot be truth for another. Truth can only be objective in its essence, i.e. independent of the individual's discretion, when all individuals recognise it in the same way. Claims made in an advertisement are considered to be incorrect if the advertiser cannot substantiate their validity in the course of their use. Whether the data supporting the claims contained in an advertisement are sufficient is decided on a case-by-case basis. The testimony and recommendations of persons whose competence does not relate to the content of the information (Law on Advertising, Article 5 [2]) is not recognised as evidence of the truthfulness of the provided claims.

According to the case law, the criterion of the truthfulness of advertising obliges the advertiser to use certain statements in advertising that prove the accuracy of these claims (JSC Gintarine Sala v. The Competition Council, No. A502-1884/2008). In this case, the data must be objective, such as a survey of labour market demand or other official statistical information, but not based only on the subjective view or perception of the attractiveness and necessity of a training program for the labour market. Advertisements of training services do not provide any official sources to indicate the need for a particular occupation in the labour market. In this case, the potential user of the service is deprived of the opportunity to check the data and to know the real situation, and only then to make a deliberate, rational and important decision on the choice of his/her future occupation. It should be remembered that advertising not only informs about a particular product or service, but also affects our economic behaviour through perception of that product or service. Having heard or seen the viable, popular or necessary occupational choice in the labour market, the consumer, through compulsion and the seeking of future prestige, may deliberately choose this option, hoping that this information is objective and correct. It leads to the development of expectations that this occupation will guarantee him/her good future prospects.

Another group of possible violations could be promises to future students about study program possibilities, for example, "... the school sincerely invites young people to choose $\langle\ldots\rangle$ the occupation that will guarantee high professional training, a work place and a stable salary" and " ... the school invites young people to choose $\langle\ldots\rangle$ the specialty that will 
guarantee high professional training, ensure that students have a job and a stable salary". Persuasion is one of the methods of psychological impact applied in advertisements. The goal of this method is to direct the behaviour of a potential user towards the anticipated direction. For example, guarantees of employment, stable salaries can be used in advertising VET as an emotional element targeted to impact consciousness and subconsciousness. Such statements are obviously misleading, because how a vocational education and training institution can ensure that a private enterprise would pay a stable salary. In reality it depends on many factors related to the private enterprise rather than the vocational education and training institution. In this case young people are guided by expectations that are difficult to implement in reality.

It should be taken into consideration that the purpose of advertising is to attract attention, to create an effect, to create an emotion by highlighting the benefits of a product or service, and often it is done by neglecting or deliberately avoiding objective truth (Remeika, 2013). Unfortunately, such behaviour violates the laws regulating the provision of information or the dissemination of advertising, because the information is manifestly false and misleading. It also violates ethical requirements and principles of social responsibility. According the document of the International Chamber of Commerce "Consolidated ICC Code of Advertising and Marketing Communication Practice" (2011), which is used to promote high standards of ethics in marketing, no communication should be such as to impair public confidence in marketing. By promising what we cannot really implement or execute, we discredit not only our educational institutions, but also public confidence in the promotion of educational services and advertising. The legal regulation of advertising is intended to protect consumers from disseminating misleading information by commercial entities, i.e. from trying to spread misleading news for propaganda purposes.

The third group of possible violations could be presentation of an institution, especially its infrastructure, for example, "the equipment used in the centres surpasses the equipment of many high schools and enterprises" and "the centre is equipped with modern, up-to-date professional equipment". The first statement may be inadmissible comparative advertising example, because this institution must have objective data or study to substantiate the claim that its equipment exceeds that of another institution. This is an obviously misleading statement, because it would be hard to carry out any such study to cover the entire Lithuania.

Attractiveness of vocational training programs is strongly linked with the quality of the practical training infrastructure. Therefore, the information about the renovation and updating of training infrastructure and equipment is widely used to create a positive impression about the latest, best, most popular and up-to date equipment and technologies used in the training process. The 
use of such information must be supported by concrete evidence proving that the equipment and technologies used by the school are in fact the best in the market. If such objective evidence is unavailable, it means misleading of a potential customer by giving him incorrect, inaccurate, and dissenting information prohibited by both the Law on Advertising and the Law on Provision of Information to the Public.

In practice, one of the most common instances of non-compliance with the criterion of justice is the use of superlative adjectives in advertising (Misleading and Inadmissible Comparative Advertising Guidelines, 2016). It is not prohibited to use a superlative adjective in advertising, but it is important to distinguish objective, i.e. objectively verifiable statements, based on actual parameters, and subjective statements of advertising (specific actual indicators of the quality of the goods or services) expressed through the use of superlative adjectives. Objective statements can be measured by accepted standards or tests, so they can be proven or rejected. Meanwhile, a subjective statement is a statement of opinion or a personal assessment of the value of non-specific goods or services (Competition Council, 2010, No. 1S-244). So, when saying that we are the best training providers in the market with the very best and most advanced equipment, we must verify whether this statement is objective or just our personal opinion about the benefits of our educational institution. It should be borne in mind that objective statements are measurable and can be proven by reasonable factual parameters.

\section{Discussion}

The present study confirms that "the key criteria students use in confirming their decision - making to enrol in the vocational institution are personal attitude towards vocational education, curriculum of the courses offered by institutions, potential for future employment after graduation, attractiveness of the campus, and tuition and scholarship" (Pimpa and Suwannapirom, 2008). In order to properly inform the public about vocational training services, it is necessary to follow the requirement of truth, i.e. the information must be accurate, impartial and objectively measurable. In addition, in terms of increasing the attractiveness of VET and marketing activities, the factors listed above should be strategically communicated to the potential students, as this information can help them to choose a VET provider consciously and responsibly.

\section{Conclusion}

Information is one of the values of modern civilisation (Markauskas, 2009) and advertising is one of the forms of information, which is protected by law in order to protect the values and rights and freedoms of other persons. Dissemination of advertising is the exchange of certain information, the 
provision and receipt of certain information, ensured by the right to freedom of information, which includes not only the right to inform, i.e. disseminate information, but also the right to receive information (Constitutional Court, 1997). Advertising can be perceived "both as a new way of disseminating information and as a new means of informing society (public)" (Webster, 2006).

In this regard it is important to take into consideration that "marketing messages used for recruiting students have an effect on student's perceptions of their relationships with their schools" (Vuori, 2015).

Legal regulation insists that advertising and information must be recognisable and truthful. This means that it has to correspond to the requirement of truth - objective truth, which can be verified under some criteria, standards or tests. Commercial practice must be conducted in good faith without materially distorting the economic behaviour of consumers, using a commercial practice to appreciably impair the consumer's ability to make an informed decision, thereby causing the consumer to take a transactional decision that he would not have taken otherwise.

Publicly available information must be fair, accurate and impartial. The understanding of quality in the educational institutions can be different, as each institution carries out educational processes in its own way, but today the marketing of educational institutions is understood in the old sense, i.e. as a purpose of introducing and selling, and the new one, as meeting customer needs (Hemsley-Brown, 2011). In order to attract more students VET establishments have to convince students of their educational potential to meet the needs of the students. Here the content of the training service and not the subjective image is the actual marketing object, because the content provides an advantage that ensures good market positions in increasingly competitive market of VET provision (Urbanovic, 2013). It is important not to violate the requirements of legal acts applicable to the freedom of information (including advertising), norms of ethics and social responsibility when developing a positive image of vocational education and training. Advertising is a valuable tool for creating an image of an organisation and for raising awareness, because it not only provides information about services, but also forms an opinion (Remeika, 2013). In addition, the image of initial vocational education is determined not so much by the actions of society, but by the vocational training systems themselves, or more specifically by the targeted efforts of its participants to improve the quality of initial vocational education, responding to the public challenges and communicating this message to the interested audiences in the communication process (Urneziene and Tolstych, 2015). 


\section{References:}

1. Catri, D.B. (1998). Vocational Education's image for the $21^{\text {st }}$ century. Digest No 188.

2. Chong, T (2014). Vocational education in Singapore: meritocracy and hidden narratives. Discourse: Studies in the Cultural Politics of Education, 35 (5), 637-648.

3. Clement, U. (2014). Improving the Image of Technical and Vocational Education and Training. Deutsche Gesellschaft für Internationale Zusammenarbeit (GIZ) GmbH. Retrieved 12/02/2018, from https://www.dcdualvet.org/wpcontent/uploads/2014_GIZ_Improving-the-Image-of-Technical-andVocational-Education-and-Training A-synthesis.pdf.

4. Druteikiene G. (2002). Organizacijos ivaizdzio kurimas: apibendrinamojo modelio link.Informacijos mokslai, 22, 97-106.

5. European Commission (2010). EUROPE 2020 A strategy for smart, sustainable and inclusive growth", $\operatorname{COM(2010)} 2020$ final. Retrieved 11/03/2018, from https://eur-lex.europa.eu/legalcontent/EN/TXT/HTML/?uri=CELEX:52010DC2020\&from=LT.

6. Hemsley-Brown, J. (2011). Market Heal Thyself: the challenges of a free marketing in higher education. Journal of Marketing for Higher Education, 21, 115-132.

7. International Chamber of Commerce (2011). Consolidated ICC Code of Advertising and Marketing Communication Practice. Retrieved 23/03/2018, from: https://iccwbo.org/publication/advertising-andmarketing-communication-practice-consolidated-icc-code/.

8. Johar, G. V. (2016). Mistaken Inferences from Advertising Conversations: A Modest Research Agenda. Journal of Advertising, 45 (3), 318-325.

9. Lauzackas, R., Danilevicius, E., Gurskiene, O. (2004). Profesinio rengimo reforma Lietuvoje: parametrai ir rezultatai. Kaunas: Vytauto Didziojo universitetas.

10. Liesionis, V., Cepaite, A. (2012). Profesinio rengimo instituciju ivaizdzio formavimo teorinis modeliavimas. Organizaciju vadyba: sisteminiai tyrimai, 62 (10), 53-67.

11. Law on Education of the Republic of Lithuania (2011). Valstybes zinios: No. 38-1804. Retrieved 23/03/2018, from https://eseimas.lrs.lt/portal/legalAct/lt/TAD/TAIS.395105/ZPzOxUEnvH.

12. Law on Vocational Education and Training of the Republic of Lithuania (2017). TAR: No. XIII-888. Retrieved 23/03/2018, from https://eseimas.lrs.lt/portal/legalAct/lt/TAD/b0b6cda0eb0a11e7a5cea258c393 $05 f 6$ 
13. Order of Minister of Education and Science Ministry and Minister of Social Security and Labour of the Republic of Lithuania (2012), No.V1090/A1-314 "On approval of the Description of the Procedure for Carrying out Vocational Guidance”. Valstybes zinios: No. 82-4284. Retrieved 23/03/2018, from https://eseimas.1rs.1t/portal/legalAct/lt/TAD/TAIS.430003

14. Order of the Minister of Education and Science the Republic of Lithuania (2014), No. V-851, On Approval of the Action Plan for the Development of Vocational Education and Training 20142016“//TAR: No. 13094. Retrieved 23/03/2018, from https://www.smm.lt/uploads/documents/svietimas/profesinis\%20mok ymas/Tinklo\%20planas.pdf

15. National Audit Office of Lithuania (2016). Public Audit Report "How was used vocational education and training opportunities ", No.VA-P50-1.Retrieved 12/01/2018, from: https://www.vkontrole.1t/failas.aspx?id=3616

16. Ministry of Education and Science of the Republic of Lithuania (2014). Ugdymas karjerai, profesinis informavimas ir konsultavimas mokyklose. Svietimo problemos analize, 19 (129).

17. Constitution of the Republic of Lithuania (1992). Valstybes zinios No. 33-1014. Retrieved 12/01/2018, from http://www3.1rs.1t/home/Konstitucija/Konstitucija.htm

18. The Law on the Prohibition of Unfair Business-to-Consumer Commercial Practices of the Republic of Lithuania (2008). Valstybes zinios: No. 6-212. Retrieved 12/01/2018, from https://eseimas.lrs.1t/portal/legalAct/lt/TAD/TAIS.312619?jfwid=bnp209gqk

19. The Law on Advertising of the Republic of Lithuania (2000). Valstybes zinios No. 64-1937. Retrieved 12/01/2018, from https://eseimas.lrs.lt/portal/legalActEditions/lt/TAD/TAIS.106104

20. Law on the Provision of Information to the Public of Lithuania (2006). Valstybes zinios No. 82-3254. Retrieved 12/01/2018, from https://eseimas.1rs.1t/portal/legalAct/lt/TAD/TAIS.280580

21. Competition Council of the Republic of Lithuania (2016). "Misleading and inadmissible comparative advertising guidelines" Retrieved 12/02/2018, from https://kt.gov.lt/uploads/documents/files/Reklamos_vertinimo_gaires. pdf

22. The Constitutional Court of the Republic of Lithuania (2006). Court Act No. 30/03. Retrieved 12/02/2018, from http://www.lrkt.lt/lt/teismo-aktai/nutarimai-isvados-irsprendimai/138/y2006 
23. The Constitutional Court of the Republic of Lithuania (1997), Court Act No. 6/96 - 10/96. Retrieved 12/02/2018, from http://www.lrkt.lt/lt/teismo-aktai/paieska/135/ta389/content

24. The Constitutional Court of the Republic of Lithuania (2005). Court Act No. 15/02. Retrieved 12/02/2018, from http://www.lrkt.lt/lt/teismo-aktai/nutarimai-isvados-irsprendimai/138/y2005

25. Supreme Administrative Court of Lithuania (2008). Case: PLLC "Gintarine sala" versus Competition Council of the Republic of Lithuania, 2008, No. A502-1884/2008.

26. Competition Council of the Republic of Lithuania, (2010). Council decision: Del atsisakymo pradeti tyrim1 del UAB "Mokescių srautas" veiksmu atitikties Lietuvos Respublikos reklamos istatymo reikalavimams", 2010, No. 1S-244. Retrieved 12/02/2018, from https://kt.gov.lt/lt/dokumentai/del-atsisakymo-pradeti-tyrima-del-uabmokesciu-srautas-veiksmu-atitikties-lietuvos-respublikos-reklamosistatymo-reikalavimams

27. Markauskas, L. (2008). Reklamos teisinis reglamentavimas: teorija ir praktika. Vilnius: UAB „Mokesciu srautas“.

28. Markauskas, L. (2009). Reklamos kaip komercines informacijos ribojimo doktrina Lietuvos Respublikos Konstitucinio Teismo jurisprudencijoje. Socialiniu mokslu studijos, 2(2).

29. Markauskas, L. (2010). Reklamos ir kitos informacijos apie prekes ir paslaugas santykis: teisinis aspektas. Socialiniu mokslu studijos, 2(6).

30. Mortimer, K. (2000). Are services advertised differently? An analysis of the relationship between product and service types and the informational content of their advertisements. Journal of Marketing Communications, 6 (2), 121-134.

31. Pimpa, N., Suwannapirom, S. (2008). Thai students' choices of vocational education: marketing factors and reference groups. Educational Research for Policy and Practice, 7 (99).

32. Remeika, A. (2013). Reklamos kampaniju kurimas ir valdymas: pazingsniui пио pradinio rinkos tyrimo iki reklamos poveikio ivertinimo. Klaipeda: VsI Socialiniu mokslu kolegija.

33. Terebeiza, Z. (2011). Tiesos nustatymo problema siuolaikiniame civiliniame procese. Socialiniu mokslu studijos, 3(3), 1015-1029.

34. The European Ministers for Vocational Education and Training, the European Social Partners and the European Commission (2010). The Bruges Communiqué on enhanced European Cooperation in Vocational Education and Training for the period 2011-2020. Retrieved $12 / 03 / 2018$

from 
http://ec.europa.eu/dgs/education_culture/repository/education/policy /vocational-policy/doc/brugescom_en.pdf.

35. UOE [UNESCO-UIS / OECD / EUROSTAT] (2018). UOE data collection on formal education: Manual on concepts, definitions and classifications.

Retrieved

$10 / 03 / 2018$,

from http://ec.europa.eu/dgs/education_culture/repository/education/policy /vocational-policy/doc/brugescom_en.pdf

36. Urbanovic, J. (2013). Studentu segmentacija formuojant universiteto rinkodaros strategija. Viesoji politika ir administravimas, 12(4), 663676.

37. Urneziene, E., Tolstych, N. (2015). Pirminio profesinio mokymo ivaizdzio gerinimas kaip kokybes vadybos tobulinimo prielaida: profesinio mokymo istaigu darbuotoju izvalgos. Andragogika, 1 (6), 153-169.

38. Vuori, J. (2015). Excellent prospects for beautiful minds: marketing international education. International Journal of Educational Management, 29 (5), 582-595.

39. Webster, F. (2006). Informacines visuomenes teorijos. Kaunas: Poligrafika ir informatika. 